\title{
An Investigation of Challenges Facing Home Gardening Farmers in South Africa: A Case Study of Three Villages in Nkokonbe Municipality Eastern Cape Province
}

\author{
Ogundiran Oluwasola Adekunle ${ }^{1}$ \\ ${ }^{1}$ Department of Agricultural Economic, Extension and Rural Development, University of Fort Hare, Alice, South \\ Africa \\ Correspondence: Ogundiran Oluwasola Adekunle, University of Fort Hare, Alice 5700, South Africa. Tel: \\ 27-083-570-3601. E-mail: ogundiranoluwasola@yahoo.com
}

Received: August 29, 2013 Accepted: October 28, 2013 Online Published: December 15, 2013

doi:10.5539/jas.v6n1p102 URL: http://dx.doi.org/10.5539/jas.v6n1p102

\begin{abstract}
This paper therefore addresses the challenges facing the home garden farmers in Eastern Cape Province of South Africa. Sixty households farmer were selected through systematic sampling from Nkokonbe municipality which were purposively selected. The small scale farmers were interviewed with the help of an interview schedule containing open and closed ended questions. Data were analysed using descriptive statistics with the help of Statistical Package for Social Sciences (SPSS). The results revealed that small scale farmers in Eastern Cape Province lack awareness of improved agricultural practices and technical knowhow because the extension staffs to farmer ratio is high. Results further reveals that they also lacked finance, experienced high interest rates on credit facilities and uncertainty of the right seed to use due to flooding of the market by many seed companies. In view of the research findings, several policy proposals are suggested. These include ensuring the availability of market information to all farmers, capacitating smallholder farmers with production and financial management skills and extension support service.
\end{abstract}

Keywords: home gardening, farmer, constraint, South Africa, agriculture

\section{Introduction}

Hunger may occur when households are unable to grow or purchase adequate food coupled with the absent of social welfare networks. It is estimated that $39 \%$ of the South African population are not food secured because of their inability to cultivate crops and low purchasing power and smallholder farmers are the potential drivers of agricultural development in less develop regions (Mgijima, 1999). As agriculture and society develops, marketing becomes more important in South Africa and other developing nations in the world. In subsistence agriculture a farmer will mainly be feeding himself and his neighbours. Home gardens denotes the traditional land use system around a homestead where numerous types of crops and vegetables are cultivated and maintained by the household with the outputs mainly for family consumption (Gautan et al., 2004). In the pass agricultural enterprises rose from 12 to 18 percent, therefore farmers have to take on commercial and marketing skills (Muchara, 2009). Responsibility in developing smallholder famers is very crucial because of the major role play by Extension agents. Before understanding the concept of marketing and its importance in the Eastern Cape Province it is imperative to understand the role of farmers in South African agriculture (Chisango \& Obi, 2010).

The most serious constraint facing home garden production relate to problems of access to production resources (inputs like water, power, fertilisers, feeds, income, services, information) and access to markets (Minot, 2003). Anderson et al. (2000) have argued that smallholder farmers operating near subsistence are more risk averse than larger farmers, and where governments especially in developing countries have tried to subsidize inputs, it led to unreliable supplies and rationing, generally favouring large scale farmers. Smallholder farmers often lack the production and marketing information necessary, particularly for new crops, varieties and breeds, where obtaining such information is difficult. Even with sufficient knowledge regarding profitability of intended investments, smallholder farmers often lack the financial reserves, where external credit is limited by lack of collateral. The smallholder farms are located mostly in the homeland area of South Africa, farming under the smallholder system 
is characterised by low levels of production technology and small sized farm holding. Basically, most smallholder farmers are poor people and they lack capital assets needed to assure their livelihoods.

Due to lack of machinery, most of them rely on labour for production. More so, agriculture's contribution to provincial gross domestic production (GDP) has reduced over the past five years but agriculture remains highly labour intensive and is a source of economic relief from poverty for the majority of the people in the rural areas (Musotsi et al., 2008). Among the constraints faced by farmers in marketing their produce, communication plays a vital role in determining the success or failure of commercialization/ marketing of the agricultural produce in rural South Africa. The extension system in the rural areas should therefore be reoriented to meet the challenges. Systemic approach in audit of the local resources will help the extension officers to a greater extent in increasing the profits of small and marginal farmers in the rural communities (Kumar \& Ravi, 2001). This is due to lack of necessary information, training, funds, discrimination, high transaction costs, technological barriers making the smallholder farmers unable to produce goods of high quality which will help them access formal markets (Magingxa \& Kamara, 2003).

\section{Purpose and Objectives of the Study}

The purpose of the study is to investigate the challenges facing smallholder farmers producing crop and vegetables in Eastern Cape Province, and suggests possible policy recommendations to smallholder farmers. The main objective of the study was to identify the constraints faced by smallholder farmers.

\subsection{The Specific Objectives Include:}

1). To identify the production and marketing challenges faced by small holder farmers in these areas as well as to assess major constraints of marketing functions (production, processing, grading, buying and selling, transportation, storage, financing, etc

2). Evaluate the support given to these farmers by government or other institutions.

3). To recommend possible strategies those policymakers can use to assist smallholder producers in their efforts to tackle these challenges.

\subsection{Literature Review}

\subsubsection{Defining a Small-Scale Farmer}

The definition of a small farm is obviously based on the size of the farm holding. According to Dent (1989) small farms are usually defined as those smaller than the average farm size at a provincial or national level. However, farm size alone is not always a good criterion for categorizing farmers. Although targeting of specific groups is difficult, it is known that small-scale farmers are those that receive only a portion of their gross income from farming, who usually have production rights rather than ownership of land, who mostly make use of family and casual labour and whose production objective may range from subsistence to infrequent or inconsistent surplus production for marketing purposes (Fraser, 1991).

\subsubsection{Importance of Smallholder Farming}

Apart from their ability to survive, smallholder farmers fulfil numerous functions in the agricultural economy. These functions make the sector important. Such functions include contribution towards food security (Rosset, 1999), equitable distribution of income and linkage creation for economic growth (Dorosh \& Haggblade, 2003). Despite the fact that smallholder farmers face difficulties in marketing, they continue to produce and survive in the face of unfavourable conditions. Supporting their views, Dorosh and Hagblade (2003) and Rosset (1999) explained that smallholder farmers have the advantage of flexible motivated family labour resources which allows them to allocate labour to activities with higher marginal returns.

\subsubsection{Farm Size of the Small-Scale Farmer}

Farm size is not a good criterion for defining small farms. For example, one hectare of irrigated peri-urban land, suitable for vegetable farming or herb gardening, has a higher profit potential than 500 hectares of low quality land in the Karoo. Turnover, or rather the level of net farm income, determines the farm size category, not the land size Land area, may be a poor economic (as opposed to geographic) measure of farm size since land is so variable in its agricultural attributes and farms of different types can require vastly different areas of land for the same value of output (Kirsten \& Van Zyl, 1998). The fact that there is not a strong small farming sector in South Africa contributes to the confusion about small-scale farming. That what many people equate to small farmers-the farmers in the former homelands farming on one hectare of dry land or less-are not the small farming types we have in mind (Kirsten \& Van Zyl, 1998). 


\subsubsection{Challenges Facing Smallholder Farmers}

For small scale farmers optimum production is very difficult as there is a lack of infrastructure which results in low productivity. This is a very important limiting factor for agricultural development. The lack of physical resource development for irrigation, water supply, housing, roads and transport are a critical problem, because basically will affect the transporting of both inputs to the farm and outputs to the markets. Small scale farmers are mostly poor farmers therefore they do not have enough money for fencing. Challenges in input and credit supply among smallholder farmers reinforce negative effects on output market development. With limited financial support and minimal use of purchased inputs, farmers' marketed surpluses will be relatively small. This leads to higher risks and transaction costs for output buyers willing to purchase from smallholder farmers (Dorward \& Kydd, 2005). Smallholder farmers are important in a nation's economy and have a potential to improve agriculture in developing countries. However, their contributions are rarely noticed as they are usually blurred by the challenges these farmers face, both in production and marketing. It is true to conclude that presently, smallholder farmers cannot compete in the market with commercial farmers. Some smallholder farmers do not participate in formal markets even after producing a marketable surplus. A range of constraints and barriers limits smallholder participation in the agricultural market. As a result most of the smallholder products are wasted after harvesting or sold at very low prices. Because of the uncertainty about prices, many farmers would take any price offered by buyers when there is a chance to participate. Many small-scale farmers are struggling to sell their goods at big markets due to some of the following challenges (Mkhwanazi, 2009).

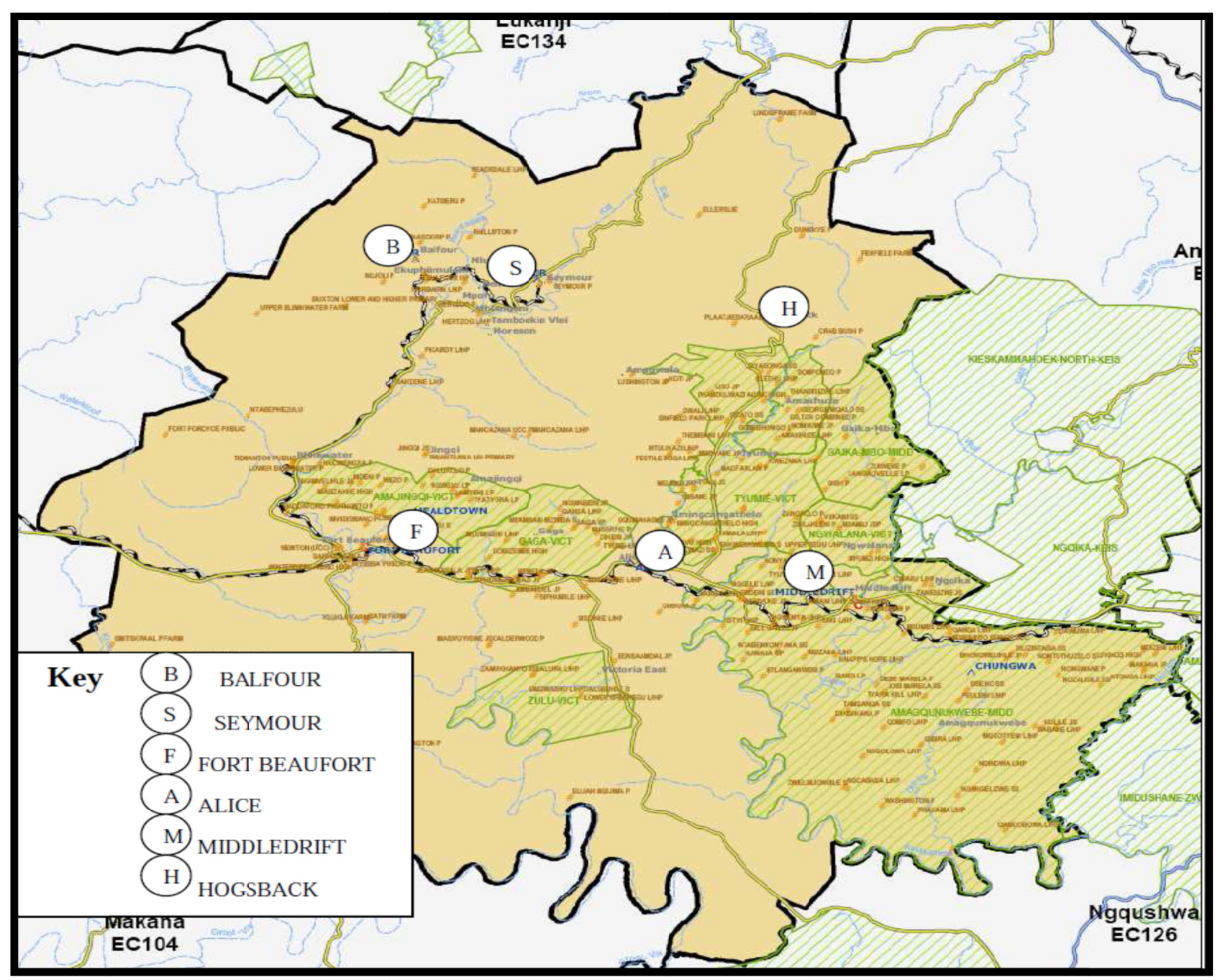

Figure 1. Nkonkobe map showing major towns (Source: Pyle, 2006) 


\section{Materials and Methods}

\subsection{Description of the Study Area}

The study was conducted in Nkonkobe which is one of the eight Local Municipalities in Amathole districts in Eastern Cape. Nkonkobe Municipality is the second largest local municipality covering $3725 \mathrm{~km}^{2}$ and making up R63 of the surface areas of the Amatole District Municipality. Nkonkobe Municipality is located in the Eastern Cape which is the second largest provinces of South Africa. Amatole is among the seven districts of Eastern Cape Province of South Africa. The administrative seat of government of Amathole is East London. Amatole symbolise Calves, obtained from the mountain range and forest which forms the northern boundary of the district. Amathole is bounded by Chris Hani to the North, OR Tambo to the North-East, the Indian Ocean to the South-East, and Cacadu to the West. Nkonkobe Local Municipality consist of five major areas which are Alice, Fort Beaufort, Hogsbacks, Middle drift and Seymour. Vegetables and livestock farming that thrives in these areas are for both commercial and subsistence. However, small and large stocks of livestock are kept in these areas for economic purpose and for subsistence. The predominant breed of livestock kept in the area is the Nguni, a local breed that is well suited to the locality. While major crops and vegetables grown include: maize, potatoes, cabbage, spinach, beetroot and carrot.

The climate varies from hot in summer to extreme cold in winter with heavy frost and snowfall along the hilly areas. The average annual rainfall is $640 \mathrm{~mm}$, and most rain falls during the summer months from October to March, with frost and sometimes snow in winter. The temperature ranges from $4{ }^{\circ} \mathrm{C}$ in July to $38^{\circ} \mathrm{C}$ in February. The place has an altitude of about 1200 meters above sea-level and the vegetation is indigenous forests (Nkonkobe Municipality, 2007).

\subsection{Sampling Procedure}

Random sampling method was adopted with no special sub-group of the population in the sample selection. The possibility of any member of the group being selected does not depend on any other member of the population. Random sampling technique was used to avoid gender and distance biases. The samples were taken from the three major areas: Alice, Fort Beaufort and Middle drift of Nkonkobe Local Municipality.

\subsection{Data Analysis Method}

A random stratified sampling method was used to draw representative samples from 3 villages in Nkonkobe Municipality, 20 respondents were interviewed in each village. The structured questionnaire was chosen, as satisfactory method to fulfil the study purpose. Structured questionnaire was prepared and administered to the sampled respondents, by face to face interviews. Existing literature on challenges faced by smallholder farmer was reviewed. The data from completed questionnaire were used for the analysis. Using a widely available and well tested package programmed Statistical Package for the Social Sciences (SPSS 11.0 Windows). Excel statistical programme was used for some descriptive explanations. Multiple regression analysis was used to determine the relevant importance of the predictors on the outcome variable (estimated income earned per year). Pearson Correlation was used to determine the estimate income earned per year.

\section{Result and Discussion}

The results of the study revealed that farmers in Nkokonbe (Eastern Cape Province) lack knowledge of improved agricultural practices and technical knowhow because extension agents did not recognized home garden farmers they focus of commercial farmers alone. Besides the extension staffs lack transport and finance to enable them reach many farmers and also carry out demonstrations and field days which would reach many farmers at a time. As a result home garden farmers in Nkokonbe, lack market and technical information that would enable them compete with the large number of traders who have flooded the vegetable market as a result of agricultural reforms. There also a weak linkage between researchers, extension staffs and farmers as a result both the extension staffs and farmers lack information on new and improved innovations.

\subsection{Challenges Faced by Home Gardening Farmers on Attainment of Seed}

Result shows that $32 \%$ of the respondents in the study area were lack of technical knowhow while $10.5 \%$ of the respondents lack farm inputs. Finding reveals that $17.9 \%$ of the respondent lack of knowledge on improving agricultural practices. Majority of the households (40.3\%) were used uncertified seed while $34.8 \%$ of the respondents lack of finance. Further analysis revealed that technology were also a major factor affecting small scale farmers which constituted $7.2 \%$. Result shows that $5.6 \%$ of the respondents were lack storage facilities while $20.1 \%$ of the household interviewed lack of fertilizer which result to low farm produce. 
Table 1. Opinion of households on factor affecting home garden in the study area $(\mathrm{n}=60)$

\begin{tabular}{ll}
\hline Factors affecting home garden production & Percentage (\%) \\
\hline Lack of technical knowhow & 32.4 \\
Lack of farm inputs & 10.5 \\
Lack of knowledge on improving agricultural practices & 17.9 \\
Use of uncertified seed & 40.3 \\
Lack of capital & 34.8 \\
Lack of technology & 7.2 \\
Poor storage facilities & 5.6 \\
Lack of fertilizer & 20.1 \\
\hline
\end{tabular}

\subsection{Access to Market Information in the Study Area}

Result shows that $80 \%$ of the respondents interviewed do not has access to market information while $20 \%$ of the respondents had access to market information. Majority of the households lack market information which result to a great lost because they don't know where, when and how to sell their farm produce.

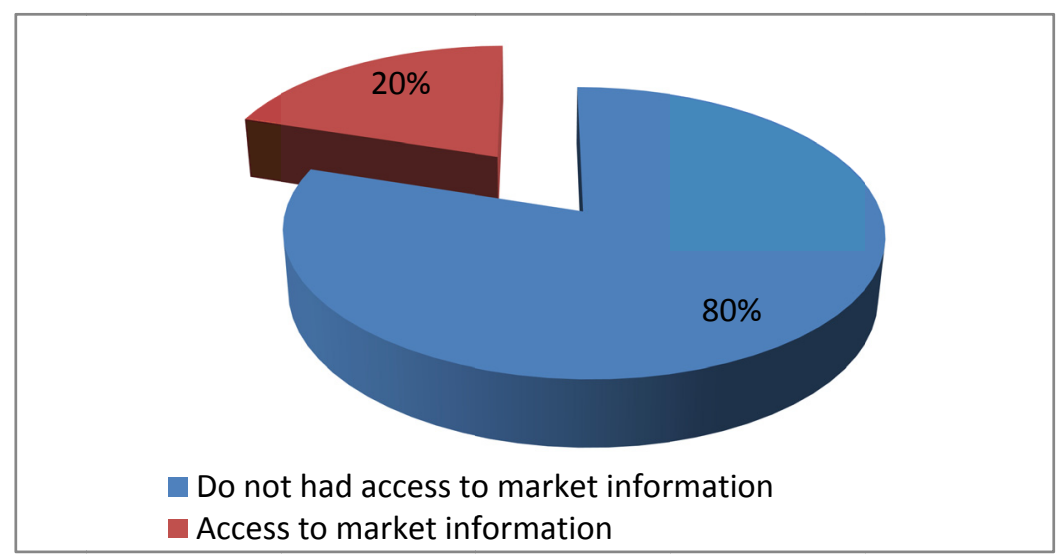

Figure 2. Market information in the study area

\subsection{Financial Support for Home Gardening Activities in the Study Area}

\subsubsection{Access to Loan}

Finding reveals the $35 \%$ of the respondent were apply for loan while $65 \%$ of the respondents did not acquire loan because they were afraid that they might be unable to pay back. Lack of knowledge of the source of loan was cited by majority of the respondents as a reason for not acquiring loans. The extension service needs to put more effort in advising small scale farmers where to source loan from. This can be achieved by the extension staff work in partnership with the lending institutions and involving them in solving farmers' problems. Lack of collateral, tough conditions imposed by lending institutions and small land sizes were some of the reasons that were cited for preventing the respondents from acquiring loan.

\subsubsection{Reason for Applying Loan}

Result shows that $18 \%$ of the respondents applied for loan to purchased improved seed while $20.5 \%$ of the respondents applied loan to bought farm inputs (hoe, garden fork, holes and watering can). Result further reveals that $35 \%$ of the respondent applied for loan to bought fertilizer. Overall, majority of the households applied for loan because they want to buy fertilizer. 
Table 2. Reason for applying loan $(\mathrm{n}=60)$

\begin{tabular}{lll}
\hline VARIABLES & & PERCENTAGE (\%) \\
\hline Access to loan & Have access to loan & 35 \\
& Do not have access to loan & \\
Reason for applying loan & Buy improved seed & 18 \\
& Buy inputs & 20.5 \\
& Buy fertilizer & 34.5 \\
\hline
\end{tabular}

\subsection{Quality of Extension Service in the Study Area}

Result shows that five per cent of the respondent mention the quality of extension was very good while $10 \%$ of the respondent signified extension service were good. Finding reveals that $43 \%$ of the respondent said extension service was poor and $41 \%$ of the households indicate the extension service was very poor. Overall, majority of the households in the study area said extension service is poor.

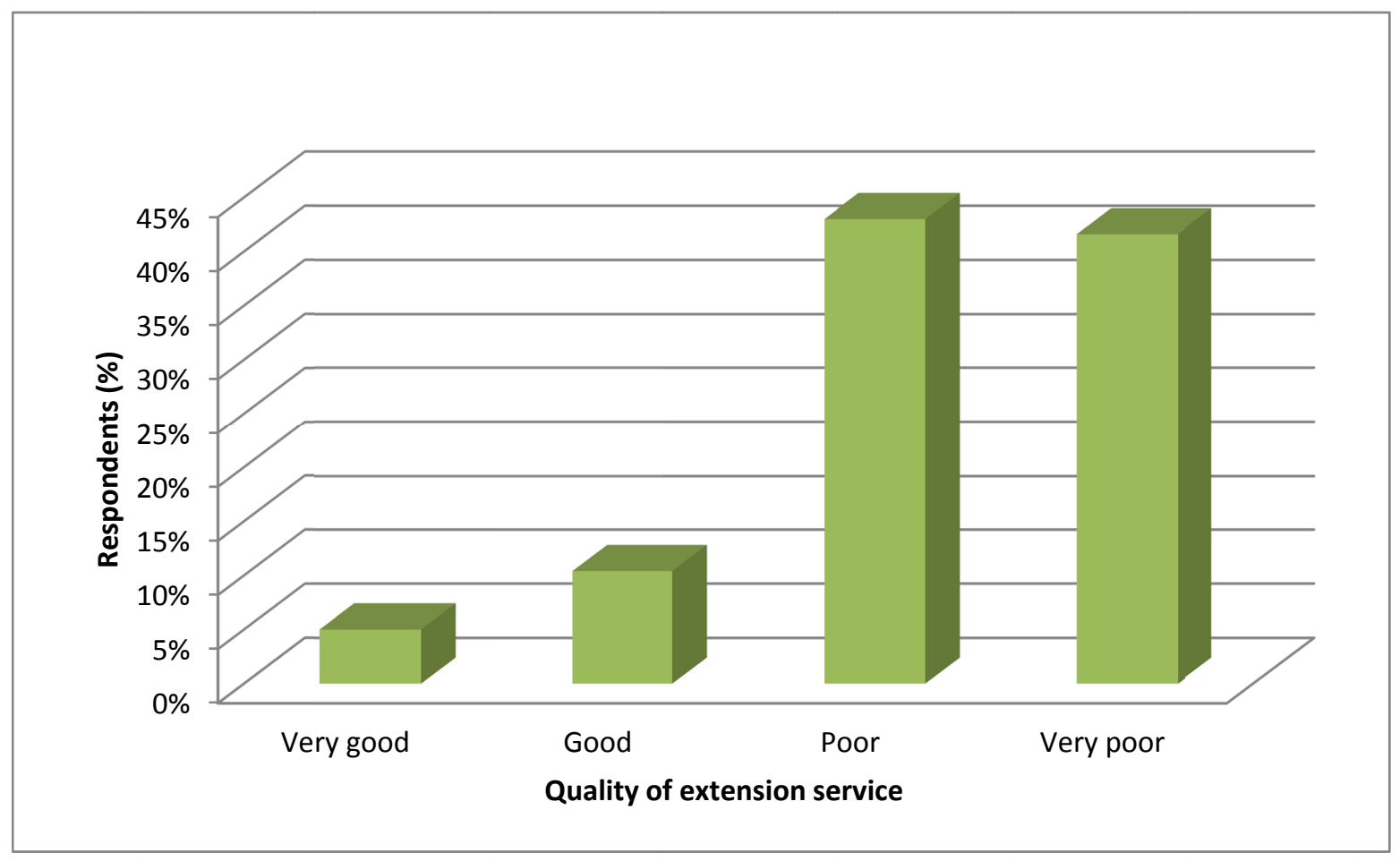

Figure 3. Quality of extension service in the study area

\section{Conclusion}

The smallholder agricultural sector in South Africa has potential to contribute to growth in the rural areas, reduce poverty and income disparity, and hence contribute to economic growth. There is need to allocate more funds for the agricultural sector within the national budget. These will facilitate hiring of more extension staff and facilitate the existing staff. There is need to improve the storage of crops by investing in both on-farm and off farm storage facilities. There is need to address the lack of incentives for farming communities by improving access to loan, strengthening agricultural institutions and developing policies to reduce market risks. The respondents confirmed that they do not perform all the marketing functions as they are lacking equipment to do so. They also pointed out that they are lacking market information and as already stated that extension offices are considered the most crucial source of information among rural communities. If this holds true, interaction with them is of great benefit to the farmers. In the study area it has been noted that the respondents who have access to extension services rely more on the government extension services. They pointed out that the government extension workers are not informed on 
their farming type. Nonetheless, respondents with access to government extension services explained that the extension workers are not consistent and some of them rarely visit their villages.

\section{Policy Recommendation}

Regard to the smallholder farmers' production and marketing challenges revealed by the experimental results, recommendations can be suggested. This section gives a series of options that can be considered in South Africa, in an effort to help smallholder farmers reach their full potential. The smallholder farmers in South Africa are facing unfair competition from the formerly supported commercial farmers. In addition, they are facing competition from internationally imported produce. For example, cheaper produce, due to subsidy policies in developed countries is imported into South Africa. In order to withstand both local and international competition, the South African government needs to consider support policies and regulation that are necessary to stimulate growth among the smallholder and emerging farmers. Majority of the farmer's interview complained about the poor services being received from extension officers. It should be emphasised that farmers can best be reached by well-trained and knowledgeable extension officers within a well-managed extension service using a participatory.

\section{References}

Anderson, L. J., Harley, P. C., Monson, R. K., \& Jackson, R. B. (2000). Reduction of isoprene emissions from live oak (Quercus fusiformis) with oak wilt. Tree Physiology, 20(17), 1199-1203. http://dx.doi.org/10.1093/treephys/20.17.1199

Chisango, F. F. T., \& Obi, A. (2010). Measuring the Technical Efficiency of Zimbabwe's Smallholder Agriculture Under Limited Mechanization and the Fast Track Land Reform Programme. Publication Paper, University of Fort Hare, South Africa.

Dent, R. J. (1989). Sustainable Agriculture for Small-Scale Farmers: A Farming System Perspective. Faculty of Agriculture, Kasetsart University, Bangkok, Thailand.

Dorosh, P., \& Haggblade, S. (2003). Growth Linkages, Price Effects and Income Distribution in Sub-Saharan Africa. IFPRI, Washington DC. Journal of African Economies, 12(2), 207-235. http://dx.doi.org/10.1093/jae/12.2.207

Dorward, A., \& Kydd, J. (2005). Making Agricultural market systems work for the poor: Promoting effective, efficient and accessible coordination and exchange. Imperial College, London.

Dovie, D. B., Witkowski, E. T. F., \& Shackleton, C. M. (2003). Direct-use value of smallholder crop production in a semi-arid rural South African village. Agricultural Systems, 76(1), 337-357. http://dx.doi.org/10.1016/S0308-521X(02)00124-5

Fraser, G. C. G. (1991). Agricultural Marketing in less Developed Countries with Special Reference in Ciskei. Unpublished $\mathrm{PhD}$ thesis, University of Stellenbosch, Stellenbosch.

Gautan, R., Sthapit, B., \& Shrestha, P. (2004). The role of home gardens to on-farm agro biodiversity management and enhancing livelihoods of rural farmers of Nepal. On farm conservation of agricultural biodiversity in Nepal: managing diversity and promoting its benefits.

Kirsten, J. F., \& Van Zyl, J. (1998). Defining small-scale farmers in the South African context Agrekon, 37(4).

Kumar, K. N, \& Ravi, R. (2001). Organisational Behaviour and Human Resources Management of Small Industry and the impact of Extension Training. Hyderabad, India.

Magingxa, L. L., \& Kamara, A. B. (2003). Institutional perspectives of enhancing smallholder market access in South Africa. Contributed Paper Presented at the $41^{\text {st }}$ Annual Conference of the Agricultural Economic Association of South Africa (AEASA). October 2-3, 2003, Pretoria, South Africa.

Mgijima, C. (1999). Situational Analysis of Food Security and Nutrition in South Africa. A Speech at the 3rd Session of the International Consultative Conference on Food Security and Nutrition as Human Rights Ransburg. South Africa.

Minot, N., \& Ngigi, M. (2003). Are Horticultural Exports a Replicable Success Story? Successes in African Agriculture: Building for the Future, IFPRI Paper 7, International Food Policy Research Institute, and Washington DC.

Mkhwanazi, M. (2009). Fresh Produce Markets: a helping hand to small-scale farmers (Vukuzenzele January 2009 ed.). Retrieved June 14, 2013 from http:// www.info.gov.za/vukuzenzele/number 21/features-06 htm 
Muchara, B. (2009). Impact of Zimbabwe's Fast Track Land Reform Programme on the Production and Marketing of Maize in the Smallholder Sector. Publication Paper, University of Fort Hare, South Africa.

Musotsi, A. A., Sigot, A. J., \& Onyango, M. O. A. (2008). The role of home gardens in household food security in Butter division of Western Kenya. African Journal of Food, Agriculture, Nutrition and Development, 8(4), 375-390.

Nkonkobe Municipality (2007). Nkonkobe Municipality-Integrated Development Plan Review Document 2006/2007.

Rosset, P. M. (1999). The Multiple Functions and Benefits of small farm Agriculture. In the Context of Global Trade Negotiations. The Institute for Food and Development Policy, Oakland.

\section{Copyrights}

Copyright for this article is retained by the author(s), with first publication rights granted to the journal.

This is an open-access article distributed under the terms and conditions of the Creative Commons Attribution license (http://creativecommons.org/licenses/by/3.0/). 